\title{
Geographically Weighted Negative Binomial Regression (GWNBR) Modeling to Analyze Factors Affecting the Number of New HIV/AIDS Cases on The Island of Java in 2019
}

\author{
(Pemodelan Geographically Weighted Negative Binomial Regression (GWNBR) untuk \\ Menganalisis Faktor-Faktor Yang Mempengaruhi Jumlah Kasus Baru HIV/AIDS Di Pulau Jawa
}

Tahun 2019)

\author{
Rifal Miju ${ }^{1}$, Achmad Prasetyo ${ }^{2}$ \\ ${ }^{1,2}$ Politeknik Statistika STIS. Jakarta, Indonesia \\ E-mail: ${ }^{2}$ 111709975@stis.ac.id,${ }^{2}$ praze@ stis.ac.id
}

\begin{abstract}
One of the problems in the health sector is the HIV/AIDS epidemic. Indonesia is in the 5th most at risk of HIV/AIDS in the Asian continent (Ministry of Health of the Republic of Indonesia, 2013). The island of Java is the area with the highest number of cases with a population of about 56 percent of the total population of Indonesia. The purposes of this study are to find out the general description of the distribution of HIV/AIDS in Java and to identify the influencing factors by considering the effect of regional proximity. This study using the Geographically Weighted Negative Binomial Regression (GWNBR). GWNBR was chose because the data in this study were overdispered. The results of the analysis show that the distribution of the number of HIV/AIDS cases is relatively clustered between regions that have high and low number of cases, this indicates a spatial effect between regions. Then the GWNBR shows that there are differences in the significance of the the population density, percentage of poor population to total population, average length of schooling, life expectancy, use of contraceptives and family planning, percentage of the number of medical personnel to total population, and the ratio of health facilities per 10,000 population were significant in some in each region and forms 9 groups of regency/municipality based on the significant variables.
\end{abstract}

Keywords: GWNBR, HIV/AIDS, Spatial

\section{INTRODUCTION}

Health is the one of several supporting sectors in determining the success of human resource development for the creation of a prosperous society. One of the emergency problems in the health sector in the world is the HIV/AIDS epidemic. This disease can be easily transmitted either through sex, needles, blood transfusions and so on. Until now AIDS has not found a cure, AIDS vaccine also does not exist. AIDS is declared a deadly disease because it has a case fatality rate of 100 percent in 5 years. Indonesia is in the 5 th most at risk of HIV/AIDS in the Asian continent (Ministry of Health of the Republic of Indonesia, 2013). Reports of the new cases continue to increase every year, since it was first discovered in 1987 until 2019 cases of HIV/AIDS have been reported by 476 (93 percent) regency/municipality. The number of reported HIV cases from 2005 to 2019 was 337564 cases, there are 5 provinces with the highest number of cases, it is DKI Jakarta, East Java, West Papua, Papua, and Central Java. The island of Java is the region with the highest number of cases with a percentage of 58.31 percent, 3 of which are the provinces with the highest number of cases in Indonesia.

The high number of HIV/AIDS cases make the world's goverments continues to implement policy to overcome this problem. One of the efforts made is through the SDGs (Sustainable Development Goals) program which is listed in one of the three SDGs goals, to ending the HIV/AIDS epidemic and other infectious diseases by 2030. Meanwhile, at the national level for handling HIV/AIDS cases, there is an agenda for handling HIV/AIDS in the National Strategy and Action Plan (HIV and AIDS control in Indonesia) which has a vision of ending the HIV epidemic in Indonesia as a threat to public health by 2030 and achieving comprehensive access to prevention, treatment, and impact mitigation.

e growth of HIV/AIDS cases which continues to increase every year has caused HIV/AIDS cases to become one of the main problems in the health sector both in the world and in Indonesia. The calculation of the number of HIV/AIDS cases in Indonesia carried out by the Indonesian Ministry of Health shows that high HIV/AIDS cases are concentrated in Java and West Papua provinces.

Based on Table 1., it can be seen that of all the additional cases of HIV/AIDS in Indonesia, 58.31 percent came from the island of Java. Th island of Java is also the most populous island in Indonesia with a percentage 
of about 56 percent of the total population (SUPAS, 2015). This large number of people will greatly allow the risk of HIV transmission to be higher.

Table 1. Number of New HIV/AIDS Cases in Java Island in 2019

\begin{tabular}{cccc}
\hline No & Province & Number of New HIV/AIDS Cases & Percentage (percent) \\
\hline 1 & East Java & 9893 & 17.26 \\
2 & DKI Jakarta & 7286 & 12.71 \\
3 & Central Java & 7243 & 12.64 \\
4 & West Java & 6379 & 11.13 \\
5 & Banten & 1801 & 3.14 \\
6 & Yogyakarta & 819 & 1.43 \\
\hline
\end{tabular}

Source: 2019 HIV/AIDS Progress Report (processed)

The number of new HIV/AIDS cases is a count data. Regression model that can be used to analyze are poisson and binomial negative model. Poisson regression can suitable fou used in the condition of equaldispersion. However, in the fact this assumption is difficult to be fulfilled. The alternative approach to overcome this overdispersion problem is by using binomial negative regression (Hilbe, 2011).

By grouping the number of new HIV/AIDS cases, it can be indicated that there is a spatial effect on the increase in the number of HIV/AIDS cases, because this disease can be transmitted easily and is not limited to an administrative boundary. This is in accordance with Tobler's law, which is that everything is related, but things that are closer are more related than things that are far away (Anselin, 1988). The development of regression model by considering spatial effect is Geoghraphically Weighted Regression (GWR). When this model is applied the negative binomial regression, then the development will be Geographically Weighted Negative Binomial Regression (GWNBR) model. Then the purposes of this study are to find out the general description of the distribution of HIV/AIDS in Java and to identify the influencing factors by considering the effect of regional proximity using GWNBR model.

\section{METHODOLOGY}

\section{HIV/AIDS}

HIV is a virus that attacks the human immune system. AIDS stands for Acquired Immune Deficiency Syndrome. Acquired means acquired, not hereditary. Immuno is related to our immune system. Deficiency means lack. Syndrome means a disease with a collection of symptoms, not a specific symptom. So AIDS means a collection of symptoms due to deficiency or weakness of the immune system formed after born.

AIDS appears after the HIV virus attacks our immune system for five to ten years or more. HIV (Human Immunodeficiency Virus) is a virus that can cause AIDS by attacking white blood cells called CD4 cells so that it can damage the human immune system. AIDS (Acquired Immuno Deficiency Syndrome) or a collection of various symptoms of disease due to the decline in individual immunity due to HIV. When an individual no longer has an immune system, all diseases can easily enter the body. Because his immune system becomes very weak, a previously harmless disease becomes very dangerous. People who are newly exposed to HIV do not necessarily have AIDS. It's just that over time his immune system gets weaker, so that all diseases can enter the body. At that stage the patient is said to have been exposed to AIDS.

\section{Public Health}

The concept of healthy living proposed by Blum (1974) in Notoatmodjo (2007) is still very relevant to use. Healthy conditions are not only physically healthy conditions but also spiritual and social in society. To create healthy conditions like this, a harmony is needed in maintaining a healthy body. Blum explained that there are four main factors that influence public health status. These four factors are factors that affect public health. The four factors consist of behavioral/lifestyle factors, environmental factors (social, economic, political, cultural), health service factors (type of coverage and quality) and genetic factors (heredity).

\section{Related Research}

In this section, an evaluation of the previous studies related or relevant to this research. Rohimah and Riyantobi (2019) in their research found that the rate of population growth, the number of health facilities, the 
number of doctors and midwives, the number of family planning extension workers and the number of poor households had a relationship with the number of HIV/AIDS sufferers in an area. The number of doctors and midwives, the number of family planning extension workers and the number of poor hou seholds will reduce the number of people living with HIV/AIDS in an area, while an increase in the rate of population growth and the number of health facilities will increase the number of people living with HIV/AIDS.

Not much different from this study, Arnawati (2016) who modeled the number of HIV/AIDS cases in Central Java using Poisson Bivariate Regression, found that the factors that influence the number of HIV cases in Central Java are the percentage of village status areas, the percentage of health facilities, the percentage of couples of childbearing ages who use condoms and the maximum percentage of the population who graduated from high school. Likewise, the factors that influence AIDS cases are the percentage of village status areas, the percentage of the number of health facilities, the percentage of couples of childbearing ages who use condoms and the percentage of the maximum population who graduated from high school in each regency/municipality in Central Java in 2016.

In addition, Ratnasari and Purhadi (2013) found that the percentage of the population using condoms and other contraceptives, the percentage of the 25-29 years age group, the percentage of the area with village status, the percentage of the population graduating from high school and the percentage of poor people in each regency/municipality had a significant effect. to the number of AIDS cases. In this study using the Bivariate Poisson regression model, it was stated that the higher the percentage of the population using condoms and other contraceptives, the percentage of the area with village status and the percentage of the population graduating from high school, the lower the number of HIV/AIDS cases. Meanwhile, the higher the percentage of the 25-29 years age group and the percentage of poor people in each regency/municipality will increase the number of HIV/AIDS cases.

A similar study was conducted by Anasi (2016) to determine the factors that influence the number of HIV/AIDS cases in East Java using the Geographically Weighted Negative Binomial Regression method by using the variables of the percentage of the population who graduated from high school, the number of medical personnel, the percentage of condom users, the percentage of status village areas, the percentage of the 25-29 years age group, and the percentage of the poor. From the results of the research conducted, it shows that the variables of the percentage of the area with village status, the percentage of condom users, the percentage of the 25-29 years age group, the percentage of the population graduating from high school, and the percentage of poor people in each regency/municipality have a significant effect on the number of HIV/AIDS cases.

\section{Framework}

Based on the theories in the literature review and previous studies that are relevant to this research that have been presented above, then the proposed framework explains the relationship between the dependent variable and the independent variables used in this study. The dependent variable in this study is "The Number of New Cases of HIV/AIDS in each Regency/Municipality in Java". Then there are 7 independent variables which are divided into three factors, namely environmental factors, lifestyle factors, and health service factors which can be detailed as follows.

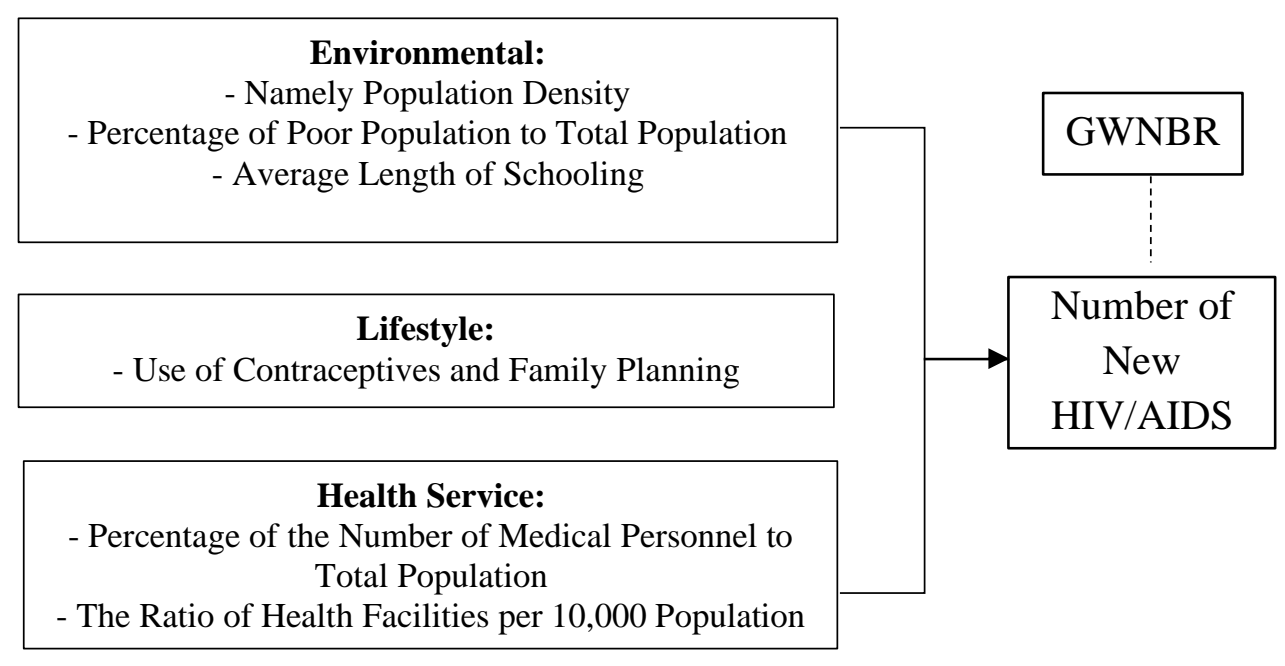

Figure 1. Research framework 


\section{Poisson Regression}

Poisson regression is distribution form for events whose probability of occurrence is very small and depends on certain time intervals with the results of observations in the form of discrete variables. In the Poisson distribution, the random variables used are non-negative integers that have the same variance, with the probability density function as follows:

$$
f(y ; \mu)=\frac{\mu^{y} e^{-\mu}}{y !} \quad, y=0,1,2, \ldots
$$

where is the average random variable $\mathrm{Y}$ which has a Poisson distribution where the average value and variance of $Y$ have a value of more than zero. Poisson regression is a form of regression analysis that is used to model data in the form of count.

\section{Negative Binomial Regression}

Negative binomial regression is a regression model used to analyze the relationship between the dependent variable in the form of count data, both in equidispersion and overdispersion conditions. With the probability density function as follows:

$$
f(y ; \mu, \alpha)=\frac{\Gamma\left(y+\frac{1}{\alpha}\right)}{\Gamma(y+1) \Gamma\left(\frac{1}{\alpha}\right)}\left(\frac{1}{1+\alpha \mu}\right)^{\frac{1}{\alpha}}\left(\frac{\alpha \mu}{1+\alpha \mu}\right)^{y} ; y=0,1,2, \ldots \text { and } \alpha>0
$$

which $\mu$ shows the parameters of the negative binomial distribution, and the mean and variance values are obtained.

\section{Spatial Effect}

Spatial effects on the data can be in the form of correlation conditions on the dependent variable error (dependency/spatial autocorrelation) as well as spatial diversity (heterogeneity) between each observation location. Both of these conditions are caused by the position of the area from one observation to other observations that are close together so that there is a spatial relationship or effect.

Geographically Weighted Regression (GWR)

The Geographically Weighted Regression (GWR) model is the development of a regression model where each parameter is calculated at each observation location. The GWR model can be written as follows:

$$
y_{i}=\beta_{o}\left(u_{i} v_{i}\right)+\sum_{j=1}^{n} \beta_{j}\left(u_{i} v_{i}\right) X_{i j}+\varepsilon_{i}, \quad i=1,2,3, \ldots, n
$$

which $\mathrm{j}$ is the independent variables to $\mathrm{j}$

\section{Geographically Weighted Negative Binomial Regression (GWNBR)}

The Geographically Weighted Negative Binomial Regression (GWNBR) model is one method that is quite effective in predicting data that has spatial heterogeneity for count data that has overdispersion (Widodo et al, 2013). The GWNBR model will generate local parameters with each location will have different parameters. The GWNBR model can be formulated as follows:

$$
y_{i}=N B\left[\exp \left(x_{i}^{T} \beta\left(u_{i}, v_{i}\right)\right), \varphi\left(u_{i}, v_{i}\right)\right], i=1,2, \ldots, n
$$

So the probability function can be written in the following form:

$$
f\left(y_{i} ; \mu_{i}, \varphi\left(u_{i}, v_{i}\right)\right)=\frac{\Gamma\left(y_{i}+\varphi^{-1}\right)}{\Gamma\left(\varphi^{-1}\right) y_{i} !}\left(\frac{1}{1+\varphi \mu_{i}}\right)^{\varphi^{-1}}\left(\frac{\varphi \mu_{i}}{1+\varphi \mu_{i}}\right)^{y_{i}}
$$

With $y_{i}$ : Observation value to $\mathrm{i}$

$y_{i}: \exp \left(x_{i}^{T} \beta\left(u_{i}, v_{i}\right)\right)$ (average for each location $\left(u_{i}, v_{i}\right)$ )

$\varphi\left(u_{i}, v_{i}\right)$ : Dispersion parameter for each location $\left(u_{i}, v_{i}\right)$

\section{Variables and Data Sources}

This study was conducted on 119 regency/municipality on the Java Island in 2019. The variables used are the number of new HIV/AIDS cases in each regency/municipality on the island of Java in 2019 as the dependent variable and seven independent variables, namely population density (X1), percentage of poor population to total population (X2), average length of schooling (X3), life expectancy (X4), use of contraceptives and family planning (X5), percentage of the number of medical personnel to total population ( 
$\mathrm{X} 6$ ), the ratio of health facilities per 10,000 population (X7), as well as the coordinates of the geographical location

The data used in this study is secondary data in the form of published data from the Central Statistics Agency (BPS), and the Ministry of Health of the Republic of Indonesia, as well as map shapefiles for each district/cit regency/municipality y on the island of Java obtained from the Central Statistics Agency (BPS). The publications used include:

1. Report on the Progress of HIV/AIDS and Sexually Transmitted Infectious Diseases (PMIS) 2019. This report was prepared by the Director General of Disease Prevention and Control (P2P) from the Ministry of Health of the Republic of Indonesia. This report contains complete and detailed information on the development of HIV, AIDS, and infectious infectious diseases (PMIS) such as Genital Ulcers throughout Indonesia. From this report, the number of new cases of HIV/AIDS in each regency/municipality on the island of Java is obtained.

2. Health Profile for 2019 for each province on the island of Java, namely the provinces of Banten, DKI Jakarta, West Java, Central Java, DI Yogyakarta, and East Java. This publication is prepared by the health office in each of these provinces. From the publication of the Health Profile, one variable is obtained, namely the ratio of health facilities per 10,000 population.

3. Dynamic table which is one of the data publications of the Central Statistics Agency which can be obtained by accessing the official website of the Central Statistics Agency (BPS). From the dynamic table obtained several variables, namely population density, percentage resident poor to the total population, the average length of schooling, the number of hope life, use of contraceptives and family planning, and the percentage of the number of medical personnel to the total population.

4. Shapefilemap of districts/cities on the island of Java prepared by the Central Statistics Agency. This shapefile containscoordinatelongitude and latitude of each regency/municipality center. This data is used for spatial analysis.

\section{Research Stages}

The stages of research carried out to carry out the analysis in this study are following:

1. Identify the non-multicollinearity assumption by looking at the VIF value for all independent variable

2. Overdispersion check. This overdispersion examination can be obtained from the Pearson Chi-Square dispersion value or can be obtained from the deviance divided by the degree of freedom, a value more than 1.

3. Forming a negative binomial regression model for knowing factors that influence the increase in the number of new cases of HIV/AIDS in the island of Java

4. Spatial heteroscedasticity testing. It was conducted to find out the spatial diversity in the data on the number of new HIV/AIDS cases in Java and the independent variables.

5. Spatial dependency testing is to determine whether the observation of a location has an effect on the observations of other adjacent locations. Testing the spatial dependence on the data on the number of casesnew HIV/AIDS in the island of Java can be use the Moran's I test.

6. To do data analysis using Geographically Weighted Negative Binomial Regression (GWNBR). With the following steps:

7. Calculating distance euclidean between observation locations based on geographic location

8. Get optimal bandwidth for each observation location

9. Calculating the weighting matrix. The weighting function used is the adaptive kernel function. This function is used because each location with other locations is considered to have a small spatial relationship. The use of the adaptive kernel function is due to the location of the observations being scattered irregularly and spread out.

10. Testing the similarity of the model between Negative Binomial Regression and GWNBR

11. Testing the significance of the GWNBR model parameters

12. Model evaluation. Comparing the Akaike Information Criterion (AIC) scores among negative binomial regression model and GWNBR then choose the model with the smallest AIC value as the best model.

\section{RESULTS AND DISCUSSION}

\section{Distribution of the Number of HIV/AIDS Cases}

The number of new HIV/AIDS cases in Indonesia in 2019 has reached 337,564 cases (Ministry of Health of the Republic of Indonesia, 2019). Most of the cases of HIV/AIDS came from the island of Java, namely 
58.31 percent of the total cases in Indonesia. The following is a picture of the distribution of the number of new HIV/AIDS cases on the island of Java:

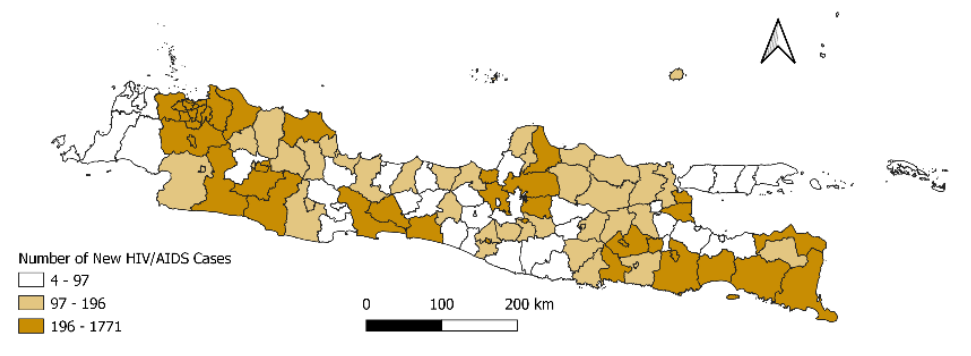

Figure 2. Distribution of the number of new HIV/AIDS cases by regency/municipality on the island of Java in 2019

Based on Figure 2., it can be seen that the distribution of the number of new HIV/AIDS cases on the island of Java forms a clustered pattern in several regions. Areas with a high category are generally surrounded by areas with a high category, as well as areas with a low category. Regions that have a high category are DKI Jakarta Province and several regency/municipality in West Java and Banten Provinces, then several regency/municipality in East Java and Central Java Provinces. Meanwhile, for the low category clustered areas, most of the provinces are Banten, Central Java, Jogjakarta, and Madura Island.

\section{Non-multicollinearity Assumption Test}

One of the assumptions that must be fulfilled in conducting regression modeling is the assumption of nonmulticollinearity, which is carried out to determine whether there is a relationship between independent variables. The existence of multicollinearity can be detected by looking at the value of Variance Inflation Factor (VIF). The following is the VIF value of each predictor variable that is used. If the VIF value obtained is less than 10, it can be said that there is no case of multicollinearity.

Table 2. VIF Value of Each Independent Variable

\begin{tabular}{lc}
\hline \multicolumn{1}{c}{ Variable } & VIF \\
\hline population density (X1) & 2.9216 \\
percentage of poor population to total population (X2) & 2.2174 \\
average length of schooling (X3) & 5.5284 \\
life expectancy (X4) & 1.6810 \\
use of contraceptives and family planning (X5) & 1.3827 \\
percentage of the number of medical personnel to total population (X6) & 1.4972 \\
the ratio of health facilities per 10,000 population (X7) & 1.2345 \\
\hline
\end{tabular}

Based on Table 2., it can be seen that the VIF value of each independent variable is less than 10 , so it can be concluded that there are no cases of multicollinearity and can proceed to the next analysis.

\section{Overdispersion Check}

Based on the results of tests conducted using R-Studio, the dispersion value or the value of the deviation ratio with the degree of freedom is 119.256 . The value is more than 1 so it can be concluded that the data used is overdispersion. So that negative binomial regression is needed to model the addition of new HIV/AIDS cases in the island Java.

\section{Modeling Negative Binomial Regression}

Table 3. Results of Negative Binomial Regression Modeling

\begin{tabular}{|c|c|c|c|}
\hline & $\operatorname{Exp}$ & Z-value & P-Value \\
\hline (Intercept) & 7.577 & 3.786 & $0.000153 *$ \\
\hline population density (X1) & $1.282 \times 10^{-4}$ & 5.283 & $1.27 \times 10^{-7 *}$ \\
\hline percentage of poor population to total population (X2) & $-8.761 \times 10^{-2}$ & -3.683 & $0.000230 *$ \\
\hline average length of schooling (X3) & $1.320 \times 10^{-1}$ & -1.406 & 0.159607 \\
\hline life expectancy (X4) & $-1.447 \times 10^{-2}$ & -0.458 & 0.647014 \\
\hline use of contraceptives and family planning (X5) & $2.075 \times 10^{-6}$ & 4.364 & $1.28 \times 10^{-5 *}$ \\
\hline percentage of the number of medical personnel to total population (X6) & $-3.754 \times 10$ & -1.248 & 0.211863 \\
\hline the ratio of health facilities per 10,000 population $(X 7)$ & $-6.299 \times 10^{-3}$ & -0.833 & 0.404992 \\
\hline
\end{tabular}


After finding a violation of the assumption of equal dispersion in logistic regression, negative binomial regression modeling was carried out. Based on Table 3., it can be seen that the predictor variables that significantly affect the increase in the number of HIV/AIDS cases on the island of Java are the dependent variable and seven independent variables, namely population density (X1), percentage of poor population to total population (X2), and use of medical devices. contraception and family planning (X5) with a significance level of 5 percent.

\section{Heteroscedasticity Test}

To be able to test for spatial heterogeneity, it can be done with the Breusch-Pagan test. Based on the results of the tests using the R Studio application, the BP test value was 31,824 and the p-value was $4.379 \times$ $10^{-5}$. If the BP test value is compared with the Chi Square table value, which is 6.3458 , it is known that the BP test value is than 6.3458 . This means that the variance between the observation locations and other locations is different. So that the resulting parameters are different for each region.

\section{Spatial Dependency Test}

Spatial dependency testing is carried out to determine whether the observation of a location has an effect on the observations of other adjacent locations. Testing the spatial dependence on the data on the number of new HIV/AIDS cases in the island Java can be done using the Moran's I test. Based on the results of the tests using the R Studio application a p-value was $6.0639 \times 10^{-7}$ with a signification level 5 percent it can be concluded that there were spatial dependences, which means that the observation of a location deoend on the observation of locations that are close together.

\section{Optimum Bandwidth and Spatial Weighting}

The weight used is the Euclidean distance between the observation areas. The obtained Euclidean distance is used to find the optimum bandwidth value and find the weight value with kernel weights. In this study the kernel weighting used is Adaptive Gaussian. The use of the adaptive Gaussian kernel weighting is because after being compared with other weights, namely adaptive bisquare, the Adaptive Gaussian weighting has the smallest AIC value.

Before forming a weighting matrix, the first thing to do is find the distance between regions. After obtaining the distance matrix, a weighting matrix is then formed to model GWNBR by entering bandwidth and distance in the kernel function.

\section{Geographically Weighted Negative Binomial Regression (GWNBR) Modeling}

\section{Model Similarity Test}

The model similarity test was conducted to determine whether there was a significant difference between the Negative Binomial Regression and Geographically Weighted Negative Binomial Regression models. Based on the results of calculations using R-Studio, the F-value is 0.950 , using 5 percent alpha, $\mathrm{F}_{(0.5 ; 111 ; 111)}=$ 0.730. Because the F-value is more than the F-table, it can be concluded that there is a significant difference between the Negative Binomial Regression and Geographically Weighted Negative Binomial Regression models.

\section{Simultaneous Testing (Simultaneous)}

Based on the calculation results using R-Studio, the deviation value for the Geographically Weighted Negative Binomial Regression model is 32.640. Then with an alpha of 5 percent obtained a value of $\chi_{(0,05 ; 7)}^{2}=$ 14,067 , it can be concluded that the variables used simultaneously have a significant effect on the dependent variable.

\section{Partial Test}

In the partial test of the Geographically Weighted Negative Binomial Regression model, it will produce different parameters and variable significance for each regency/municipality on the island of Java, due to the diversity between regions. By using a significance level of 5 percent, each regency/municipality on the island of Java is grouped based on the significant variables in Table 4. The regional groupings can also be presented in the form of a map in Figure 3. 
Table 4. Grouping of Regencies/Cities in Java Island Based on Significant Variables

\begin{tabular}{|c|c|c|}
\hline Group & Significant Variable & Name of Regency/Municipality \\
\hline 1 & $\begin{array}{l}\mathrm{X} 1, \mathrm{X} 2, \mathrm{X} 3, \mathrm{X} 4, \mathrm{X} 5 \\
\mathrm{X} 6, \mathrm{X} 7\end{array}$ & Tasikmalaya, Cimahi \\
\hline 2 & $\begin{array}{l}\mathrm{X} 1, \mathrm{X} 2, \mathrm{X} 3, \mathrm{X} 4, \mathrm{X} 5 \\
\mathrm{X} 7\end{array}$ & Magelang, Sragen \\
\hline 3 & $\begin{array}{l}\mathrm{X} 1, \mathrm{X} 2, \mathrm{X} 3, \mathrm{X} 4, \mathrm{X} 6 \\
\mathrm{X} 7\end{array}$ & $\begin{array}{l}\text { Thousand Islands, South Jakarta, East Jakarta, Central Jakarta, West Jakarta, } \\
\text { North Jakarta, Bogor, Sukabumi, Cianjur, Bandung, Garut, Sumedang, Subang, } \\
\text { Purwakarta, Karawang, Bekasi, West Bandung, Bogor, Sukabumi, Bandung, } \\
\text { Bekasi, Depok, Cimahi, Tasikmalaya, Purworejo, Klaten, Wonogiri, Grobogan, } \\
\text { Magelang, Kulon Progo, Bantul, Gunung Kidul, Sleman, Yogyakarta, Pacitan, } \\
\text { Ponorogo, Magetan, Ngawi, Pandeglang, Lebak, Tangerang, Serang, Tangerang, } \\
\text { Cilegon, Serang, Tangerang South }\end{array}$ \\
\hline 4 & $\mathrm{X} 1, \mathrm{X} 2, \mathrm{X} 3, \mathrm{X} 4, \mathrm{X} 7$ & $\begin{array}{l}\text { Boyolali, Sukoharjo, Karanganyar, Demak, Semarang, Temanggung, Surakarta, } \\
\text { Salatiga, Semarang }\end{array}$ \\
\hline 5 & $\begin{array}{l}\mathrm{X} 2, \mathrm{X} 3, \mathrm{X} 4, \mathrm{X} 5, \mathrm{X} 6 \\
\mathrm{X} 7\end{array}$ & $\begin{array}{l}\text { Pangandaran, Banjar, Lumajang, Jember, Banyuwangi, Bondowoso, Situbondo, } \\
\text { Probolinggo, Pasuruan, Sidoarjo, Mojokerto, Jombang, Lamongan, Gresik, } \\
\text { Bangkalan, Sampang, Pamekasan, Sumenep, Malang, Probolinggo, Pasuruan, } \\
\text { Mojokerto, Surabaya, Batu }\end{array}$ \\
\hline 6 & $\mathrm{X} 2, \mathrm{X} 3, \mathrm{X} 4, \mathrm{X} 5, \mathrm{X} 7$ & $\begin{array}{l}\text { Cilacap, Banyumas, Purbalingga, Banjarnegara, Kebumen, Wonosobo, Blora, } \\
\text { Rembang, Pekalongan, Pemalang, Tegal, Brebes, Pekalongan, Tegal }\end{array}$ \\
\hline 7 & X2, X3, X4, X6, X7 & $\begin{array}{l}\text { Kuningan, Cirebon, Majalengka, Cirebon, Trenggalek, Tulungagung, Blitar, } \\
\text { Kediri, Malang, Madiun, Tuban, Kediri, Blitar, Madiun }\end{array}$ \\
\hline 8 & $\mathrm{X} 2, \mathrm{X} 3, \mathrm{X} 4, \mathrm{X} 7$ & Pati, Kudus, Jepara, Kendal, Batang, Nganjuk, Bojonegoro \\
\hline 9 & $\mathrm{X} 2, \mathrm{X} 3, \mathrm{X} 6, \mathrm{X} 7$ & Indramayu \\
\hline
\end{tabular}

Figure 3. shows the grouping of regency/municipality in Java Island according to significant variables. It can be seen that, regions that have the same group are relatively close to each other. This happens because of the influence of spatial effects between regions.

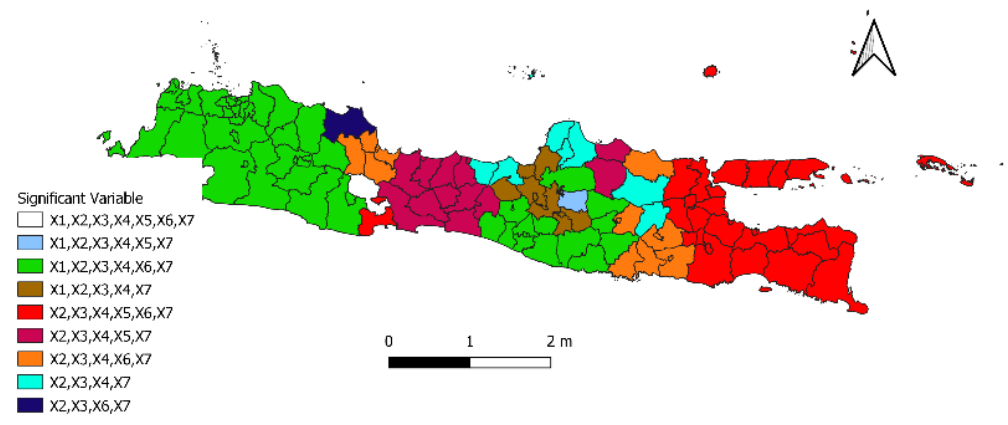

Figure 3. Grouping of Regency/Municipality Areas in Java Island According to Significant Variables

As one of the following examples, a parameter test in Cirebon is presented to determine the significance of the variables and their interpretation.

Table 5. Estimation of GWNBR modeling parameters in Cirebon Regency.

\begin{tabular}{ccc}
\hline Parameter & Estimate & $\mathrm{Z}$ \\
\hline$\beta_{0}$ & 7.576631995 & 134647,465 \\
$\beta_{1}$ & $7.04062 \times 10^{-5}$ & 1.21456424 \\
$\beta_{2}$ & -0.087011807 & -147.59848 \\
$\beta_{3}$ & -0.13157983 & -351.79483 \\
$\beta_{4}$ & -0.010364945 & -2.5769171 \\
$\beta_{5}$ & $7.6574 \times 10^{-7}$ & 0.76659776 \\
$\beta_{6}$ & -37.54246882 & -397368139 \\
$\beta_{7}$ & -0.005472156 & $-6,7529978$ \\
\hline
\end{tabular}


Based onTable 5., it can be seen that there are 5 significant variables, namely the percentage of the poor population to the total population (X2), the average length of schooling (X3), life expectancy (X4), the percentage of the number of medical personnel to the total population (X6), the ratio health facilities per 10,000 population (X7). Then the model formed is:

$$
\begin{aligned}
\ln (\hat{\mu})=7.577 & +7.041 \times 10^{-5} X_{1}-0.087 X_{2}-0.132 X_{3}-0.010 X_{4}+7.657 \times 10^{-7} X_{5}-37.562 X_{6} \\
& -0.005 X_{7}
\end{aligned}
$$

So, it can be concluded that for every 1 percent decrease in the percentage of poor people to the total population (X2) in Cirebon, the number of HIV cases will increase by $\mathrm{e}^{-0.087}=0.917$ times assuming other variables are constant. For every 1 unit increase in the average length of schooling (X3) in Cirebon, the number of HIV cases will decrease by $\mathrm{e}^{-0.132}=0.8763$ times assuming other variables are constant. For every 1 unit increase in life expectancy (X4) in Cirebon, the number of HIV cases will decrease by $\mathrm{e}^{-0.010}=0.99$ times assuming other variables are constant. For every 1 percent decrease in the percentage of the number of medical personnel to the total population (X6) in Cirebon, the number of HIV cases will increase by $\mathrm{e}^{-27,562}=0$ times assuming other variables are constant. For every 1 unit increase in the ratio of health facilities per 10,000 population (X7). in Cirebon, the number of HIV cases will decrease by $\mathrm{e}^{-0.005}=0.995$ times assuming other variables are constant

\section{Model Evaluation}

To determine the best model of all the models used, it can be done by looking at the AIC criteria in each model. The model with the smallest AIC value will be selected as the best model.

Table 6. AIC Value of Each Model

\begin{tabular}{cc}
\hline Model & AIC \\
\hline Negative Binomial Regression & 1457.98 \\
GWNBR & 1324.26 \\
\hline
\end{tabular}

Based on Table 4., it can be seen that the Geographically Weighted Negative Binomial Regression model has an AIC value that is smaller than the Negative Binomial regression model, so it can be said that the GWNBR model is better for modeling the increase in the number of new HIV/AIDS cases in regency/municipality on the island of Java in 2019.

\section{CONCLUSIONS}

Distribution of the number of new HIV/AIDS cases in regency/municipality on the island of Java forms a clustered pattern in several areas. Regions that have high category generally surrounded by areas with a high category, as well as areas with a low category. In the area that own the high category is in DKI Jakarta Province and a number of regencies in the provinces of West Java and Banten which are in the vicinity, then several regency/municipality in the provinces of East Java and Central Java. Meanwhile, for the low category clustered areas, most of the Banten Province, Central Java, Jogjakarta, and the island of Madura.

The variance between observation locations and other locations varies. So that the resulting parameters are different for each region. Then there is a spatial dependency, which means that the observation of a location depends on the observation of locations that are close together. Then the GWNBR model shows that there are differences in the significance of the variables in each region and forms 9 groups of regency/municipality based on the significant variables.

\section{ISSUES FOR FURTHER RESEARCH}

For the next researcher recommended to apply the method mixed Geographically Weighted Negative Binomial Regression (MGWNBR) or using the Geographically Weighted Bivariate Negative Binomial Regression (GWBNBR) method by separating HIV sufferers and AIDS sufferers as the dependent variable. Adding variables to the lifestyle dimensions such as the use of syringes as independent variables. 


\section{REFERENCES}

Anasi, Raras. (2016). Analisis Faktor-Faktor Yang Mempengaruhi Jumlah Kasus HIV di Jawa Timur Tahun 2014 Menggunakan Geographically Weighted Negative Binomial Regression. Diploma Thesis. Institut Teknologi Sepuluh Nopember

Anselin, L. (1988). Spatial Econometris: Methods and Models. Dordrecht: Kluwer Academic Publisher

Arnawati, W. N. (2016). Metode Regresi Poisson Bivariat Dalam Pemodelan Jumlah Kasus HIV Dan AIDS di Jawa Tengah.

BPS Statistics Indonesia. (2019). Indeks Pembangunan Manusia. Jakarta: Badan Pusat Statistik. Retrieved from www.bps.go.id.

Bappenas. (2014). Prakarsa Strategis MDGs Acceleration Framework Penanggulangan HIV dan AIDS di Indonesia Tahun 2014. Jakarta: Direktorat Kesehatan dan Gizi Masyarakat.

Dinas Kesehatan Provinsi Banten. (2020). Profil Kesehatan Provinsi Banten Tahun 2019. Serang: Dinas Kesehatan Provinsi Banten.

Dinas Kesehatan Provinsi DI Yogyakarta. (2020). Profil Kesehatan Provinsi Di Yogyakarta. Yogyakarta: Dinas Kesehatan Provinsi DI Yogyakarta.

Dinas Kesehatan Provinsi DKI Jakarta. (2020). Profil Kesehatan Provinsi DKI Jakarta. Jakarta: Dinas Kesehatan Provinsi DKI Jakarta.

Dinas Kesehatan Provinsi Jawa Jawa Barat. (2020). Profil Kesehatan Provinsi Jawa Barat. Bandung: Dinas Kesehatan Provinsi Jawa Barat.

Dinas Kesehatan Provinsi Jawa Tengah. (2020). Profil Kesehatan Provinsi Jawa Tengah. Semarang: Dinas Kesehatan Provinsi Jawa Tengah

Dinas Kesehatan Provinsi Jawa Timur. (2020). Profil Kesehatan Jawa Timur Tahun 2019. Surabaya: Dinas Kesehatan Provinsi Jawa Timur.

Hilbe, J. M. (2011). Negative Binomial Regression. New York: Cambridge University Press.

Kementerian Kesehatan RI. (2020). Laporan Perkembangan HIV AIDS dan Penyakit Infeksi Menular Seksual (PIMS) Tahun 2019. Jakarta: Pusat Data dan Informasi Kementerian Kesehatan RI.

Notoatmojo, S. (2007). Promosi Kesehatan dan Ilmu Perilaku. Jakarta: Rineka Cipta

Ratnasari, N. T., \& Purhadi. (2013). Pemodelan Faktor yang Mempengaruhi Jumlah Hiv dan Aids Provinsi Jawa Timur Menggunakan Regresi Poisson Bivariat. JURNAL SAINS DAN SENI POMITS Vol. 2, No.2, 213-218.

Riyatin, Suryono, \& Haryanti, T. (2019). Faktor Penyebab Penularan HIV/AIDS pada Wanita di Kabupaten Sragen. Jurnal Ilmu Kesehatan Masyarakat Berkala, 14-22.

Rohimah, S. R., \& Riyantobi, A. M. (2019). Model Spasial Otoregresif Poisson Untuk Mendeteksi FaktorFaktor Yang Berpengaruh Terhadap Jumlah Penderita HIV/AIDS di Jakarta Timur. Jurnal Statistika Dan Aplikasinya (JSA) Vol. 3 No.2, 35-44. 